\title{
INDEX TO Volume 24 (2006)
}

\section{ARTICLES}

COHEN, Yolande. Protestant and Jewish Philanthropies in France: The Conseil National des Femmes Françaises (1901-1939) (Vol. 24, No. 1, 74)

FARGE, Arlette. Corps et politique : individu et société (Vol. 24, No. 1, 1) FRIEDBERG, Erhard. Le CPE est mort-et maintenant? (Vol. 24, No. 3, 89) GOLDHAMMER, Arthur. Did Historians Make History? (Vol. 24, No. 2, 102) GOLLAIN, Françoise. Les débats autour du mouvement pour la décroissance (Vol. 24, No. 2, 115)

GUÉNIF-SOUILAMAS, Nacira. The Other French Exception: Virtuous Racism and the War of the Sexes in Postcolonial France (Vol. 24, No. 3, 23)

IHL, Olivier. The Market of Honors: On the Bicentenary of the Legion of Honor (Vol. 24, No. 1, 8)

JABBARI, Eric. Law and Politics in Interwar France: Pierre Laroque's Search for a Democratic Corporatism (Vol. 24, No. 1, 93)

JACKSON, Jeffrey H. Artistic Community and Urban Development in 1920s Montmartre (Vol. 24, No. 2, 1)

LEBOVICS, Herman. The Musée du Quai Branly: Art? Artifact? Spectacle! (Vol. 24, No. 3, 96)

MASCLET, Olivier. Des quartiers sans voix: Sur le divorce entre la Gauche et les enfants d'immigrés (Vol. 24, No. 3, 5)

NEULANDER, Joelle. Family Values and the Radio: The 1937 Radio Elections and the Miniseries France (Vol. 24, No. 2, 26)

PESTRE, Dominique. Scientists in Time of War: World War II, the Cold War, and Science in the United States and France (Vol. 24, No. 1, 27)

ROSS, George. Myths and Realities in the 2006 "Events" (Vol. 24, No. 3, 81)

SEIGEL, Jerrold. "Spiritualizing the Material" and "Dematerializing the World" in Modernist and Avant-Garde Practice: On the Wider Import of a Distinction Debora Silverman Develops in Van Gogh and Gauguin (Vol. 24, No. 2, 71)

SILVER, Kenneth E. Matisse at Vence: An Epilogue to Van Gogh and Gauguin: The Search for Sacred Art (Vol. 24, No. 2, 81) 
SILVERMAN, Debora. Painting, Self, and Society at the Cusp of Abstraction: Comments on Art and Comparative Cultural History (Vol. 24, No. 2, 91)

SINEAU, Mariette. Paradoxes of the Gender Gap in France (Vol. 24, No. 1, 40) SPITZER, Alan B. Born in 1925 (Vol. 24, No. 2, 46)

THOMSON, Belinda. Comparing Lives: Issues of Balance in Biographical Writing (Vol. 24, No. 2, 60)

TISSOT, Sylvie. Y a-t-il un « problème des quartiers sensibles »? Retour sur une catégorie d'action publique Vol. 24, No. 3, 42).

VALAT, Bruno. Les Assurances sociales: une contribution à la modernisation de la société française dans l'entre-deux-guerres? (Vol. 24, No. 1, 114)

VIGUIER, Frédéric. Introduction (Vol. 24, No. 3, 1)

VIGUIER, Frédéric. "Maintaining the Class": Teachers in the New High Schools of the Banlieues (Vol. 24, No. 3, 58)

WEILL, Nicolas. What's in a Scarf? The Debate on Laïcité in France (Vol. 24, No. 1, 59)

\section{REVIEW EsSAYS}

DOWNS, Laura. Saving France's "Lost Boys": Vichy and the Reform of Juvenile Justice in France (Vol. 24, No. 1, 124)

GOLLAIN, Françoise. Temps de travail, temps de la vie (Vol. 24, No. 1, 137)

GREEN, Nancy L. Of Tour Buses and Politics: American Tourists in France in the Twentieth Century (Vol. 24, No. 3, 130)

SALA PALA, Valérie. Novembre 2005: sous les émeutes urbaines, la politique (Vol. 24, No. 3, 111)

STROMBERG CHILDERS, Kristen. The Evolution of the Welfare State: Social Rights and the Nationalization of Welfare in France, 1880-1947 (Vol. 24, No. 2, 129)

\section{Book Reviews}

BOSWELL, Laird. Le Communisme: Une passion française by Marc Lazar (Vol. 24, No. 1, 144)

CHATRIOT, Alain. Le Patricien et le Général: Jean-Marcel Jeanneney et Charles de Gaulle 1958-1969 by Eric Kocher-Marboeuf (Vol. 24, No. 2, 141)

COLE, Alistair. Le Vote européen, 2004-2005: De l'élargissement au référendum français by Pascal Perrineau (Vol. 24, No. 3, 150)

DUTTON, Paul V. Fathers, Families, and the State in France, 1914-1945 by Kristen Stromberg Childers (Vol. 24, No. 3, 137)

GISQUET, Elsa. La Condition foetale by Luc Boltanski (Vol. 24, No. 3, 145)

HOWORTH, Jolyon. L'Amérique vraiment impériale? Entretiens sur le vif avec Frédéric Bozo by Stanley Hoffmann (Vol. 24, No. 3, 147)

JONES, Colin. Science and Polity in France: The Revolutionary and Napoleonic Years by Charles Coulston Gillispie (Vol. 24, No. 3, 135) 
LEHNING, James R. The Pride of Place: Local Memories and Political Culture in Nineteenth-Century France by Stéphane Gerson (Vol. 24, No. 2, 139)

LEWIS-BECK, Michael S. Parties and the Party System in France: A Disconnected Democracy? by Andrew Knapp (Vol. 24, No. 2, 149)

LEVY, Jonah D. Silicon and the State: French Innovation Policy in the Internet Age by Gunnar Trumbull (Vol. 24, No. 1, 147)

MORGAN, Kimberly J. Généalogie de la morale familiale by Rémi Lenoir (Vol. 24, No. 3, 140)

RAULIN, Anne. Black Skins, French Voices: Caribbean Ethnicity and Activism in Urban France by David Beriss (Vol. 24, No. 3, 143)

REGGIANI, Andrés. Bringing the Empire Back Home: France in the Global Age by Herman Lebovics (Vol. 24, No. 2, 146)

\section{INDEX OF BOOKS REVIEWED}

BERISS, David. Black Skins, French Voices: Caribbean Ethnicity and Activism in Urban France reviewed by Anne Raulin (Vol. 24, No. 3, 143)

BOLTANSKI, Luc. La Condition foetale reviewed by Elsa Gisquet (Vol. 24, No. $3,145)$

CHILDERS, Kristen Stromberg. Fathers, Families, and the State in France, 1914-1945 reviewed by Paul V. Dutton (Vol. 24, No. 3, 137)

GERSON, Stéphane. The Pride of Place: Local Memories and Political Culture in Nineteenth-Century France reviewed by James R. Lehning (Vol. 24, No. 2, 139)

KNAPP, Andrew. Parties and the Party System in France: A Disconnected Democracy? reviewed by Michael S. Lewis-Beck (Vol. 24, No. 2, 149)

KOCHER-MARBOEUF, Eric. Le Patricien et le Général: Jean-Marcel Jeanneney et Charles de Gaulle 1958-1969 reviewed by Alain Chatriot (Vol. 24, No. 2, 141)

LEBOVICS, Herman. Bringing the Empire Back Home: France in the Global Age reviewed by Andrés Reggiani (Vol. 24, No. 2, 146)

GILLISPIE, Charles Coulston. Science and Polity in France: The Revolutionary and Napoleonic Years reviewed by Colin Jones (Vol. 24, No. 3, 135)

HOFFMANN, Stanley. L'Amérique vraiment impériale? Entretiens sur le vif avec Frédéric Bozo reviewed by Jolyon Howorth (Vol. 24, No. 3, 147)

LAZAR, Marc. Le Communisme: Une passion française reviewed by Laird Boswell (Vol. 24, No. 1, 144)

LENOIR, Rémi. Généalogie de la morale familiale reviewed by Kimberly J. Morgan (Vol. 24, No. 3, 140)

PERRINEAU, Pascal. Le Vote européen, 2004-2005: De l'élargissement au référendum français reviewed by Alistair Cole (Vol. 24, No. 3, 150)

TRUMBULL, Gunnar. Silicon and the State: French Innovation Policy in the Internet Age reviewed by Jonah D. Levy (Vol. 24, No. 1, 147) 